\title{
Michel Ecochard in Lebanon and Syria (1956-1968). The spread of Modernism, the Building of the Independent States and the Rise of Local professionals of planning
}

\author{
Eric Verdeil \\ Université de Lyon, CNRS - UMR Environnement Ville Société \\ 18, rue Chevreul 69007 Lyon \\ eric.verdeil@normalesup.org
}

Eric Verdeil is an urban geographer. He has a $\mathrm{PhD}$ from Paris 1-Panthéon Sorbonne University. After having lived and researched in Beirut, Lebanon as a fellow of the Institut français du Proche-Orient, based in Beirut, he moved to Lyon where he is now a Research Fellow of the Centre National de Recherche Scientifique. He teaches at the Institut d'urbanisme de Lyon.

His dissertation dealt with the reconstruction of Beirut and the history of planning in Lebanon. He has published several books, including Atlas du Liban. Territoires et société (IFPO, 2007), and with Taoufik Souami, Concevoir et gérer les villes. Milieux d'urbanistes du sud de la Méditerranée (Economica-Anthropos, 2006). His book Beyrouth et ses urbanistes. Une ville en plan is due to be published soon. 


\section{Michel Ecochard in Lebanon and Syria (1956-1968). The spread of Modernism, the Building of the Independent States and the Rise of Local professionals of planning}

The architect and planner Michel Ecochard has had a long career in developing countries, from its first works in Syria under the French rule, until the 1970's. He represented the modernist and functionalist approach to planning in a time of modernization. In this article, we concentrate on his work in Lebanon and Syria between the end of the 1950's and the 1960's. He prepared the master plans of Beirut and of Damascus. Those works represented the end of an era rooted in colonial planning. It was also the beginning of a new time, with the local planners taking on, sometimes sharing, sometimes contesting Ecochard's visions. Building on recent scholarship on the circulation of planning ideas, we focus on the reception of Ecochard's proposals. Though most political elites and planning professionals shared most Ecochard's views, the political circumstances and the changing social conditions led to adjustments and reorientations. The new planning framework was also a major factor of change.

Key words

Damascus, Syria, Beirut, Lebanon, Planning, Modernism, Master plans, Michel Ecochard, Local professionals.

The architect and planner Michel Ecochard (1905-1985) is already a wellknown practitioner of colonial planning in Syria, Lebanon and Morocco at the end of the French colonial era [1]. But his later work in the third world is less known, apart from Ghorayeb’s accounts [2]. Interestingly, even his obituary in the journal Environmental design almost fully omitted the years after the end of the Moroccan experience in 1953 [3]. This article intends to highlight his work from the end of the 1950's till the end of the 1960's. During these years, no longer as a civil servant, but at the head of a small consulting firm based in Paris, he travelled between France, Lebanon and Syria where he could rely on his fame and on his professional networks. During the same years and later, he was also granted commissions in other Middle Eastern and African cities for planning schemes and architecture projects. His work in those later places remains understudied and will also be outside the remit of this article.

What will be addressed here is Ecochard's Middle Eastern career, which offers an interesting opportunity to address the dissemination of urban planning expertise in the post-colonial years. First, Ecochard was, if not a disciple, at least an admirer of Le Corbusier. As such, he contributed the dissemination of the modernist planning ideas into the Third World. He also carried a rigorous conception of the general interest and 
of the public duty regarding the built environment, thus advocating a strong role for the State in planning matters. Beyond his doctrinal influence, his trajectory is also interesting because it clearly illustrates that urban planning in the post-colonial states of Syria and Lebanon originated from former colonial initiatives and developed without breaking with the legal and conceptual framework that had been established under the colonial rule (the Mandate). Ecochard played a key role in this smooth transformation, since he was called to help in the strengthening of the Lebanese and of the Syrian planning administrations.

He participated in the setting up of new national laws and was committed for the master plans for the capitals. As a special consultant with access to the ruling elites and administration, Ecochard contributed to the dissemination of new planning agendas in the new States. But our purpose is also to understand the interactions between Ecochard and the local planning milieus. Many of the Lebanese and Syrian planners who began their careers before or during this period had been collaborators, associates and alter egos of Ecochard. On some occasions, he also provoked strongly antagonistic reactions, on nationalistic grounds or for ideological reasons. This paper will explore the diverse networks of his collaborators in both countries, and in so doing, acknowledge his and their central role in any analysis of the circulation and dissemination of planning ideas.

\section{The Dissemination of Planning ideas: the issue of the local professionals}

The spread of Modernism, and more globally, the spread of planning practices and ideologies in Southern countries needs to be seen in the context of several strands in the development of planning ideas and practice. A first landmark in research has been the investigation of the colonial policies, of which planning is considered a 
major pillar, as shown by various authors [4]. In this framework, planning has been seen as a tool for domination. Another orientation of research has been to consider the colonial planning practices as a set of experiences in places less constraining than mother countries, before implementing these practices in the motherland. Such a perspective has been widely explored, for the former French colonies, about the Morrocan [5] and Algerian [6] cases, and later on about Subsaharian Africa [7].

But post-colonial circulations of architecture and planning practices and ideologies do not fit exactly in such a framework, even if obvious links exist between colonial and post-colonial practices. The study of post-colonial practices can be addressed from three different perspectives, which will be exemplified in this paper.

The first of these is a reflection on the circulations of planning ideas, as Ward has framed them in his book on the diffusion of planning ideas and practices in the western capitalist world [8]. He proposes a typology of diffusion situations based on the nature of geopolitical relationships that can be applied for our purpose, particularly the inequality of political and economical power between the emitting and the receiving country, in a way that also encompasses the level of planning culture and organization in the receiving country.

But the shift from the inter-western perspective to the north - south perspective, of course leads to a second perspective paradigm. The spread of modernism toward the south implies a certain level of adaptation to the assumed specificity of the Southern contexts. The socio-economical specificities of the Southern contexts lead to the setting up of new development and planning ideologies, that cannot be conceived as 'western' models exported from outside, since they have been elaborated from southern experiences [9]. At the same time, the circulations of expertise in the field of planning, architecture and development (often interrelated) 
should not be understood without reference to the geopolitical contexts. The case of Doxiadis, closely linked to the American agenda vis-à-vis Third world nations, illustrates that idea perfectly [10].

The third perspective on planning history in Southern countries has shown the benefits of adopting the local lens, in order to understand how local institutions and groups can desire, use and orient foreign conceived, or inspired, planning projects according to their own agendas and in the framework of their relations with other local or foreign actors. Nasr and Volait's book’s contributors offer several studies illustrating that paradigm [11]. In Sanyal's book on the Comparative Cultures of planning, the chapters of the section dedicated to the industrializing countries explore how the construction of the State and the political agendas of the ruling class shape the culture of planning [12]. In Indonesia for instance, the colonial legacy of planning is filtered and adapted in further historical stages according to the new balance of power and the ideological orientation of the state [13]. In another collaborative book, Souami and Verdeil [14] attempt to delineate what has been called 'local milieus of planners', insisting not only on the creation of national institutions of planning and of national ideas of planning (what Sanyal's book mainly does) but also on professionals, architects engineers and planners themselves, their education, their ideology, their careers and their professional and economic objectives, as well as their political and social commitments. These kinds of criteria contributed to the framing of planning projects and must be carefully understood.

This paper will build on these previous approaches and apply them to the cases of Syria and Lebanon. The two countries share a common legacy of urban management under the Ottoman rule and later, under the French Mandate. But the split into two countries and two states with dissimilar projects and backers resulted, as 
early as the twenties and the thirties, and then more and more, in very different relationships between the society and the State and, the purpose of this paper, in planning cultures. First, Beirut as the capital of the French Mandate and the port city of the Levant, experienced more dramatic growth than the city of the hinterland. Secondly, in Syria and particularly in Damascus, the colonial State has used town planning in order to impose its imprint on the city in a context of upheavals and armed resistance to the French domination. In Beirut, most decisions regarding town planning had been very soon shared with the municipality and were less militarised. The colonial power in Lebanon also left the local as well as the French capitalist forces with less constraining and more negotiable urban guidelines than in Damascus. Accordingly, the Lebanese capital developed in a way sometimes depicted as anarchic while its counterpart was more controlled [15]. The period from the independence years after World War 2 until the mid seventies is a time where the two states built their administration according to the varying and diverging local political contexts, and particularly their planning administration.

The case of Ecochard in Syria and Lebanon provides an interesting opportunity to intersect the issues of the circulation of planning ideas and practices from the North to the South with the problematic of state and administration building in former colonial states. On the one hand, the aim is to understand the itinerary of a modern architect and planner in his numerous travels from France to Syria and Lebanon, as well as between Syria and Lebanon, and between both countries and other ones. On the other hand, we would like to look at the institutionalisation of planning in Syria and Lebanon at the time of Ecochard, seeing in which way the French planner contributed to the establishment of planning administrations, to the formation of local planners and to the dissemination of a planning ideology and in 
particular, to the shaping of the built environment, directly or indirectly, through the plans and ideas he used to propose.

This parallel analysis of the two countries and Ecochard's development as a French colonial planner, gives an opportunity of going beyond the accounts found in the current monograph literature, which is often privileged in the existing research about those countries, because of the constraints of historical and archival work, as well as of the personal background and commitment of the researchers in certain national issues. These national approaches are at risk of overlooking similarities and of overweighting national peculiarities and the cross perspectives may help in overcoming this.

I should say at the outset that this paper rests on a better knowledge of the Lebanese planning history than of the Syrian one. The information and understanding on Lebanon was gathered while writing my $\mathrm{PhD}$ dissertation. It is thus based on the extensive reading of archives in Lebanese libraries and administrations, as well as in French archive deposits [16]. About 25 interviews with direct witnesses or protagonists were carried out between 1997 and 2001 and provided complementary materials. In Syria, I have relied mainly on secondary sources: two academic unpublished research reports [17], a few published articles and planning reports in several Syrian and French libraries and archives centres. I also carried out six interviews with witnesses and former professionals [18]. Without offering the same wealth of information as in the Lebanese case, this provides at least challenging exploratory results. 


\section{Michel Ecochard, a herald of the modern architecture and planning in the Third}

World

Several works and retrospectives on Ecochard's work have already gathered a lot of information on his professional career [19]. This section only provides the main elements that are helpful for our purpose.

\section{i.From archaeology to planning: Syrian and Lebanese experiences under the French rule}

Ecochard, a young graduate in architecture from the Beaux Arts, arrived in Syria in 1930. He was looking for an experience outside France. The French authorities in Syria were hiring young professionals in their administration. He was assigned to the Archeology Service. There he contributed to several projects in various Syrian places. He renovated the Azzem Palace in the Old Damascus and built for the Head of the French Institute a modern building, as well as a national museum. He worked together with French archaeologists, and he discovered Roman monuments as well as the Islamic architecture. His major contribution was, alongside others, the discovery of the organisation of antique water networks. His findings and drawings were later published. This is one of the reasons why he was embedded in the team in charge of drafting a master plan for Damascus in 1932-34. He served as a local correspondent for the Danger brothers, whose firm based in Paris was commissioned for the task [20]. His knowledge of the antique and Arab heritage and architecture, particularly of large monuments, would later be one of the major influences on his practice of modern planning.

In 1938, he was appointed as the head of the Planning Administration for Syria, a body he was commissioned to create. This fact not only offers proof of the cleverness and talents of the young architect but also highlights the lack of professional French expertise in Syria, at a time when resources were scarce. The local administration recruited more and more local engineers from Syrian or Lebanese 
universities as well as those trained in foreign institutions [21]. The experience of chief planner in Syria consisted of the drawing up several master plans for the main cities of Syria [22].

In 1941, Ecochard was also sent to Beirut. The city had already been studied but the resulting plan remained a draft. In the new war context, the administration urgently needed reorganization. Ecochard engaged with passion in the project but he faced numerous hurdles and conflicts with local or French private interests. The young planner advocated ambitious projects like new road schemes or a garden city. But his conception of the public interest led him to propose expropriation of large plots and the creation of a state or municipally controlled planning administration. It contradicted several other private projects and was not approved [23].

\section{ii.The Moroccan Experience: a planning agenda for the Third World}

After the war, Ecochard participated with Le Corbusier, among others, in a study journey to the USA. He became at the time a member of the CIAM and a proponent of modern architecture and planning. In 1946, he was sent to Morocco, a French protectorate. He would remain there, as the head of the planning department, until 1952 [24].

During his stay in Morocco, he had to cope with the rural exodus and the growth of cities. The major city was Casablanca, the main harbour of the country, which had been, at the beginning of the French Protectorate, a kind of showroom for modern planning with Lyautey and Prost's initiatives. But the tremendous growth of Casablanca soon made the first plans, whose implementation had been delayed and opposed, not relevant anymore. Ecochard set up an ambitious modernist and functional master plan. He also contributed master plans for the development of several areas. 
One of his major and innovative contributions was about the launching of housing projects for the poor. The 'neighbourhood' plans were based on a reproducible grid and on the observation of the inhabitants' practices and habits rather than on great architectural gesture. Ecochard was aware that he was coping with a problem of a far greater reach than the single Moroccan case. As such, his work, in association with other architects like Candilis at the Atlelier des Bâtisseurs (ATBAT) was a contribution to the debate about city development in the third world and was recognized as such in the IXth CIAM Conference in 1953[25].

Another salient point of his Moroccan work, particularly in Casablanca, was once again, and like in Beirut, his numerous fights with the local bourgeoisie regarding real estate projects and speculation. Pressures from the governor led him to resign from his position in 1952.

\section{iii.Ecochard as Global Planner and Architect}

Ecochard then jumped to a later stage of his career. He established a private firm, first with the young modern architects Riboulet and Thurnauer (until 1958), then as sole owner. He undertook planning and architecture projects in various countries (see Table 1). He first reactivated his networks in Lebanon, where he was awarded several contracts and projects, but he also got commissions in central and western Africa, at the end of the colonial era and at the beginnings of the independence era, as well as in Pakistan and in several Arab or Islamic countries (Iran, Kuwait, Oman). It was only after 1960 that he also got contracts in France. As an architect outside France, he was mostly engaged in the design of schools, hospitals, universities and museums (Pakistan, Lebanon, Kuwait, Ivory Coast, Congo, Cameroon, Bahrein). His clients were mostly government but also, at some occasions, the UNO or private firms. 
Table 1: Michel Ecochard's main planning contracts and projects (1953-1978).

\begin{tabular}{|l|l|}
\hline $1953-55$ & $\begin{array}{l}\text { Study on the housing of refugees in Pakistan, } \\
\text { commissioned by UNO [26] }\end{array}$ \\
\hline $1956-58$ & Master plan for Saida (Lebanon) \\
\hline $1956-58$ & $\begin{array}{l}\text { Master plan for the New town of Sabendé, Guinea, } \\
\text { Client: Pechiney (French aluminium firm) }\end{array}$ \\
\hline $1959-60$ & Master plans for Jounieh and Jbeil (Lebanon) \\
\hline $1960-64$ & Various studies in Lebanon \\
\hline 1962 & Master plan for the ZUP of Martigues (France) \\
\hline 1963 & Master plan of Beirut and suburbs (Lebanon) \\
\hline $1963-67$ & Master plan of Dakar (Senegal) \\
\hline $1964-68$ & Master plan of Damascus (Syria) \\
\hline 1967 & Master plan of Tabriz (Iran) \\
\hline 1969 & Regional master plan for Corsica (France) \\
\hline 1971 & $\begin{array}{l}\text { Master plan for the redevelopment of the city center of } \\
\text { Meshed (Iran) }\end{array}$ \\
\hline 1973 & Master plan for the new capital of the Sultanate of Oman \\
\hline 1978 & Master plan for the city center of Teheran \\
\hline
\end{tabular}

Source : French Institute of Architecture (http://

archiwebture.citechaillot.fr/.../FRAPN02_ECOMI_REPERAGE.pdf).

At the end of the fifties, his career speeded up, with contracts in numerous countries, and recognition in France through architectural and planning contracts and his participation on many institutional committees. During the 1960's and the 1970's, he became one of the major French speaking voices speaking about and involved in planning in third world countries, holding various conferences and publishing some papers in specialised journals [27]. His once Syrian collaborator Samir Abdulac termed him a "urbaniste tiers-mondiste" (an urban planner for the third world) [28]. During these years he never lost the link with the countries of his first practice and he wrote another book and several papers on Islamic architecture. His last lectures were about the way to conciliate the urban Islamic heritage and modern planning.

\section{Michel Ecochard and the setting up of the planning agenda in Lebanon and Syria in the 1960's}

From the mid 1950’s to 1968, Ecochard spent a lot of time in Lebanon and Syria, being involved in the preparation of the master plans of Beirut and Damascus among others tasks. In both countries, it was a time of great political transformation 
and planning the capital city was high on the agenda, in relationship to the prospects of modernization of each country. In both countries, Ecochard's proposals were ambitious but faced opposition and were not implemented as the French planner had intended, which angered him. Yet, in both cases, Ecochard remained in the following years a prominent reference for the planners and the system of planning ideas in each countries. But his name and actions were also contested.

\section{i. Back to Lebanon: the last opportunity to arrange Beirut}

After Ecochard had been fired from his Moroccan position, he had to rest on his previous networks in order to nurture the private consulting firm he had opened in Paris. In this respect, his Lebanese friends welcomed him and he was able to obtain several architectural projects from private clients (schools, hospitals, touristic projects...). In 1956, after the earthquake that hit the Jezzine area, the Lebanese government set up a National Authority for reconstruction that granted Ecochard's team the task of planning the city of Saida, the capital of south Lebanon, and to build in that city new low-income neighbourhoods [29]. In 1958, he also obtained commissions for planning the rapidly increasing coastal cities of Jounieh and JbeilByblos. It is probably when he worked in Jounieh that he met the newly elected Président Fouad Chehab, who lived in the area. At the time, Ecochard had written a programmatic memorandum on the principles of planning in Lebanon [30]. Chehab launched in the following years an ambitious program that probably relied on some of those ideas (and also picked up some from others studies and projects prepared in the same time, like Doxiadis’s and those of the Planning council [31]). In 1962, Chehab created a new Planning ministry, a new Town Planning law was passed and General Directorate for Town Planning and a Higher Council for Town Planning were created. 
At the same time, Chehab launched a program for regional development with another French consultant, IRFED (a team led by the Dominican Father Louis Joseph Lebret).

From the point of view of international relations, Chehab adopted a milder position than his predecessor, Chamoun, who ranked among the close American allies in the region. Chehab was closer to the Arab socialist countries. He had also been trained in the French Army and knew Charles de Gaulle. He was prepared to turn back to France, the former colonial master whose influence the first independent governments of Lebanon had tried to counterbalance with the American alliance [32]. The call of French experts had a geopolitical meaning.

Michel Ecochard's work in Beirut was in line with President Chehab's development program. The French planner was entrusted with the Qarantina project for the clearance of a slum at the entrance of Beirut (1960) and with the master plan for the governmental cities (a project of an administrative district gathering several ministries and public bodies, 1961). Ecochard conceived the later as a draft for a master plan of Beirut and its suburbs, and he convinced the administration to entrust him with the project, which he completed in 1963. In 1961, he had established an office in Beirut and had to nurture his team with new projects. Then he undertook a master plan for the main roads of the agglomeration and a detailed study for the renovation of the commercial city centre(1964). He also studied plans for the Northern highway between Beirut and Jbeil.

The archives reveal that Michel Ecochard never ceased to lobby the President and the administration in order to go further and to be awarded the projects' studies. In his letters, he appears as a passionate advocate for planning Beirut, a task he had long been reflecting on [33]. At a time when Beirut were experiencing a rapid growth, Ecochard claimed to organize the growth in the suburbs, thanks to a new road scheme 
and to a functional zoning scheme, as well as with new planned neighbourhoods for housing (that he called 'new towns') [34]. His approach was clearly functional and based on Le Corbusier's principles of the separated functions (work, housing, leisure, circulation), at the scale of the city as well as the scale of the neighbourhoods, even if few studies were made at so small a scale.

The Lebanese government assigned a committee to supervise the study and the proposal and to turn it into a decree. In September and October 1964, two decrees were approved. The first was a zoning ordinance setting up the urban guidelines and the density in the various parts of the city and the other was the approval of the road master plan in the suburbs. It had to be completed with detailed plans, which would be the case in 1967. Ecochard strongly rejected the paternity of the project, claiming it had been greatly altered. Indeed, the 'new towns' proposals were let aside by the Lebanese committee and the authorized densities were much higher than what Ecochard had foreseen. The Lebanese planning administration argued it had neither the human resources nor the financial means to implement the new towns projects. As for the second issue, the rise in the building density reflected the strong pressures the representatives of the land owners and the real estate lobby exerted on the committee and the government [35].

After the end of Chehab's term and the adoption of the transformed Ecochard's proposal, the French planner did not work anymore in Lebanon. He had felt betrayed and had publicly criticized the government and the administration. In 1964, a new president, Charles Helou, took over and the political alliances soon shifted. The new government therefore gave up most of its ambitious goals. Nevertheless, in the following years, the name of Ecochard remained attached to the Beirut's suburbs master plan he had later disowned. Many amendments would later 
alter the master plan of the suburbs, but, until now, it still bears the name of the French planner. More, the word Ecochard was sometimes to be used as a common noun meaning 'master plan' in popular speaking [36]. The French planner emerged for posterity as the planner with the modern idea of planning in Lebanon, and was as such revered or hated.

\section{Damascus: the planning of so beloved a city}

In contrast to the involvement of Ecochard in the modernization of the Lebanese planning, of which the master plan of Beirut was the prominent landmark but not the sole achievement, his work in Damascus was more limited, even if coming back to Syria was a return to his beginnings. Even more than Lebanon, Syria had experienced strong political transformations in the recent years. Between 1958 and 1961, Syria and Egypt had merged in the United Arab Republic, with Gamal Abdel Nasser for President. The Syrian administration experienced major changes and in many cases was reshaped according to the Egyptian model. It was also the case for the administration of planning. Before 1958, the planning department at the ministry of public works used to be called tajmîl al-mudun, which means 'embellishment of the city’ which derived from the French influence in Syria (by 1924, a French law had made compulsory for all French cities more than 10.000 inhabitants to set up "plans d'aménagement, d'embellissement et d'extension”). After 1958, planning depended upon the ministry of rural and municipal affairs and was called takhtît al-mudun, a word literally meaning the planning of the city, already used in Egypt [37].

By 1961, a coup ended the Syrian-Egyptian Union but the socialist orientation lasted. In 1963, the Ba'ath party had taken the reins and it claimed the modernization of Syria according to socialist and collectivist options. At the time, the Syrian regime developed links with the socialist countries and Bulgarian [38] and Polish experts 
were appointed in various administrations, including the planning one. Greek (Doxiadis) and Italian consultants were also hired for planning the provincial cities of Syria [39]. The geopolitical framework resulted in the fact that the Syrians did not rely only on western expertise.

Ecochard's return nevertheless shows that the Syrian authorities were flexible and pragmatic. According to Alexius Shaakar, engineer and later head of the planning administration, Ecochard had heard about the call for tender for planning the provincial cities, and though Damascus was not included in it, he went to the planning administration. His interlocutors, impressed by his knowledge of the city and his previous experience in the country, commissioned him to develop a master plan. For Ecochard, the return to Damascus was also a fruit of his love for the old city and its monuments he knew better than any other planners, as is clearly explained in the introduction to the master plan. But he never developed relationships with the Syrian officials and heads of administration as strongly as he did in Beirut. Conversely, he worked out the first stage of the project in Paris and paid only a few visits to Syria until its completion.

The elaboration of the master plan of Damascus lasted 4 years (1964-1968) instead of 18 months as initially intended, mainly because the process of discussion and of approval requested long administrative stages that roused Ecochard's ire. In order to placate him, the Syrian administration granted him detailed studies of the road networks scheme [40]. One of the major concerns of the master plan was the prospect of a huge increase of population in the 25 following years and the physical growth of the city. The site of Damascus is an oasis at the mouth of the Barada river coming from beyond the mountain of Qassium. The oasis was an important agricultural area adjacent to the city, and a precious landscape. Its preservation from 
urbanization was a major goal. The master plan recommended to extend the city along the mountain east- and westwards and studied carefully the new neighbourhoods. Another important goal of the master plan was the modernization of the major arteries network, with new highways toward Jordan, Lebanon and the North (Aleppo Baghdad).

But the administration also requested from the team a plan to modernize the inner city and new streets were drawn. It was particularly the case of the new Ommeyad entrance along the Barada toward Marjeh square and the Thawra (Revolution) street from Hamidiyeh Gate, in front of Salah ed Din Citadel toward Aleppo square, both of which cut through the ancient urban fabric of the neighbourhoods outside the walled city. This major modernization project was a high priority for the administration and the government launched it as soon as 1966, before the approval of the whole master plan. The project had a symbolic meaning, since it linked the Ommeyad Square with Hamidiyeh and Hamidiyeh with the modern city of the 1930-1950’s where most State administrations were established [41]. It also fitted the modern need for opening wide streets for an increasingly car-equipped middle and upper-class, at a time when the traffic was congested in the narrow street network.

If the administration pushed for such a project to be quickly implemented [42], some of Ecochard's ideas were received with less enthusiasm. It was the case with his projects in the old city. The French planner wanted to uncover the architectural marvels of the ancient city, particularly the old medieval castle, not less beautiful in his eyes than the Louvre in Paris[43]. He felt the same about the Ommeyad Mosque in front of which he wished to open a new square. He also wanted to excavate the Roman remnants near and underneath Salah ad Din's grave and to create a kind of archaeological garden. This concern was directly dictated by his deep 
knowledge of the history of the city and of his dealings with the archaeologists at the French Institute 30 years before. More broadly, he advocated the need to open the ancient city to the car, the only way, according to him, to sustain the commerce inside the city and to help restore and improve the dwellings. He therefore proposed to widen a number of streets and to arrange parking places here and around. The Syrian administration did not welcome the excavations projects, at least because of the heavy cost of expropriation. They also refused the clearance of all the wall around the Citadel which would have lead to the demolition (of at least parts) of the popular souk Hamidiyeh, the battling heart of the city where hundreds of shopkeepers were working and where every Dimashqi used to shop, but whose architecture Ecochard dismissed [44]

The episode of the Damascus master plan reveals the acceptance by the Syrian authorities of the modernist agenda as far as it was related to the modernization of the modern city, its adaptation to the new times, the central role Damascus had to play at the heart of Syria and as a crossroads of the Arab world. But regarding the ancient city, the Syrian authority did not share the views of the planner. Ecochard's insistence on bringing the Arab monuments or the Roman ruins to the fore was feared to be too expensive or to raise the opposition of the population in the name of a conception of history and of beauty they were far from understanding and sharing.

After the master plan was finished in 1967, before being officially approved in 1968, Syria experienced a new political change. In the aftermath of the 6 days war, a triumvirate led by the Ba'athist Salah ed Din Bitar took power to be, in turn, replaced in 1970, by Hafez al-Assad. The new leader introduced major changes in Syria and he implemented a more pragmatic policy. The 1967 war had created a new situation. A large, unexpected flow of refugees from the Israeli-occupied Golan Heights settled in 
camps and in informal settlements in various parts of the city. At the same time, Hafez el-Assad intended to strengthen his grip on the society and therefore sought to give satisfaction to the social groups who were supporting the regime, most of all, the armed forces and the civil servants. Some areas initially planned to remain gardens and agricultural areas, like Kafar Soussa, were progressively built over. From 197273, Hafez al-Assad called for the implementation of huge housing programs. In the following years, several new towns developments were studied and planned in three locations that Ecochard had not considered for urbanization: in Dummar on the old Beirut road, behind the Jabal Qasium; and in Dimas, on the new highway to Beirut [45]. Such programs were intended for military men and built by the newly created Institution for Military Construction (Dimas) [46] or for civil servants or middle categories close to the regime (teachers, engineers) that were allowed to settle in ‘cooperatives'. In 1979, at last, UNESCO labelled the walled city of Damascus, as a World Heritage site and consequently, this move hampered the modernization projects inside the city, leading to the abandon of the few Ecochard's ideas that the government was still considering, like the widening of some small streets to the traffic, even though some works were carried out until 1983 [47]. The demolition had aroused a new concern for the historic heritage. It led to sharp criticism of Ecochard's views [48].

Ecochard's intervention in Damascus was the end of an era that had its roots in the colonial period, where Ecochard embodied a grand narrative of planning the capital city according to modern and functional principles, including the upstaging of ancient monuments at the detriment of the old urban fabric. The new regime implemented selected parts of Ecochard's master plan that reinforced the role and the image of the capital of Syria. But they also introduced those ideas which served new 
needs and new social categories in new places, thus changing the conception of the Damascus agglomeration far from the outcomes Ecochard had foreseen.

\section{Michel Ecochard and the birth of local professional milieus in Lebanon and Syria}

Ecochard's legacy is not limited to the iconographic idea of the two cities, nor to the conception of a modern and functional planning, nor to his help in shaping the laws and administration of planning in both countries (mainly in Lebanon). The French planner was also to a certain extent the father of the local planners, most of them he knew personally and sometimes had trained. But his proselytism about the role of the State, his fighting spirit, as well as his nationality had aroused critics from local professionals who were also his competitors. The new understanding of heritage appeared as a new line of cleavage with the younger generation. His conception of the planner as the chief of large operations and of small units was also challenged by the rise of a new professional and economical model of the engineering profession in the Middle East, the Arab multidisciplinary consulting firms.

\section{Ecochard, a model for the local planners}

In 1943, Ecochard was invited to deliver the inaugural speech at the Academie Libanaise des Beaux-Arts at the launching of the first school of architecture as such in Lebanon and Syria. His lecture was mainly about planning. During this time, he was also invited in several gatherings where he preached for a strong planning policy in Lebanon [49]. As shown above, he renewed his proselytism at the end of the fifties. His Lebanese colleagues relied on his fame and authority in order to convince the government of implementing ideas they also shared [50].

As far as the records show, Ecochard had never before been involved in any teaching of architecture or planning, at least on a regular basis, be it in France or the Middle East. But several of his lectures or papers demonstrated a desire to reach out 
to the next generation. The journal Horizons techniques du Moyen Orient, circulated by the association of the alumnis of the Ecole Supérieure d'ingénieurs de Beyrouth (ESIB) published a paper by him in 1961 where he explained his view about planning. Other papers in the same journals were written by some of his collaborators or trainees and had the same pedagogical content. This journal was also read in Syria by former graduates from the ESIB. The discussion in the same journal of the master plan for Beirut and its suburbs evidenced the strong support a lot of the young engineers devoted to him [51].

In addition, Ecochard had strong ties with some leading characters of the engineering milieu in Beirut, like Amin Bizri or Henri Eddé, who both occupied the position of President of the Order of Engineers and later minister of Public Works. They collaborated with Ecochard for private architecture projects as well as for various planning studies. They belonged to the committee in charge of supervising the master plan of Beirut and to the council that drafted the new planning law in Lebanon.

For the purpose of his studies in Beirut, Ecochard opened offices in both cities where he hired local collaborators. He also had in his staff two Japanese architects and planners, Banshoya and Gono. Both contributed to the Beirut's studies before Banshoya had a leading role in delivering the Damascus plan. He then settled in Syria where he also contributed to studies in Aleppo [52].

The links of Ecochard with the Syrian milieu were less strong. The deep political changes in Syria from the end of the fifties resulted in the marginalization of the socio-economic elite of the country and possibly, of some of the professional leading characters (like the engineer Philippe Assouad, a former high ranking executive at the ministry of Public works in Damascus who moved to Beirut). 
Ecochard had few links with the new people in authority, most of whom belonged to a new generation.

\section{Contesting Ecochard}

The master plans of Beirut and Damascus were landmark documents in professional milieus but they aroused some criticism. In the case of Beirut, we have shown several dimensions of the contrasting views. A group of leading engineers, including Farid Trad and Henry Naccache, criticised some of the choices of Ecochard for the road networks as well as for the density program. Their reflections can be explained by the fact these engineers had previously made alternative proposals that Ecochard did not integrate or even contradicted in his master plan [53].

The Lebanese professional milieu, even if it shared a lot of Ecochard's ideas, may have felt him as a competitor taking their place because of his links with the government. It was a time when the Order of Engineers was trying to establish itself against the government. One of its major concerns was to fight the governmental tendency to hire foreign consultants. The Order was defending the market of the Lebanese professionals against the use of foreigners, both on economic and nationalistic grounds, in the context of the Independence years [54].

There seems to be no evidence of such contestation of Ecochard's work in Damascus. There, the most contentious issue was the planning of the inherited urban fabric in the old city. In the 1970s, Ecochard's ideas for the historic core of the city were more and more criticised. The UNESCO World Heritage label in 1979 was the result of the mobilization of part of the professional milieu against the modernist ideas of Ecochard, embodied in the creation of the Friends of Damascus Society in 1977. It culminated in a conference held by the Order of Engineers in 1982 [55]. 


\section{The renewal of the milieus}

The sixties were also the end of an era. The episodes of the master plan of both capital cities must be understood as a sign that the newly independent States in Lebanon and Syria used urban planning as a tool at the service of State building. Therefore, in both countries, new administrations were established that hired engineers and architects coming more and more from local universities [56]. In Lebanon, the private firms were granted a lot of contracts from the State for various studies. In Syria, the private firms were less numerous but engineers and university professors were also granted some commissions.

In both countries, the administrations were more adequately staffed and new young engineers or architects remained in charge of the planning administration for a longer time. This was so in the case of Alexius Shakar, born 1934 in Syria. Thanks to a grant of the Syrian ministry of work, he studied architecture and city planning from the University of Washington (Seattle) where he graduated in 1958. Immediately hired at the ministry of Rural and Municipal affairs, he became general director (mudir al'am) of the planning service in 1964 while only 30 years old. He served in that position until 1983 and was appointed vice-minister of Housing in 1979. One of his first actions, once in office, was to set up an internal memo defining the principles and the rules that the master plans had to follow. It is still in existence today [57]. In Lebanon, the architect Mitri Nammar (1967-1973) and then the engineer Mohammed Fawaz (1973-1992) served as heads of the planning directorate and their action was similar to that of Shakar [58]. With their team, and thanks to their long spell in charge, they have played a crucial role in establishing the planning administration and practices. They have been at the interface between the foreign and private planners, limiting the direct and personal links of these with the politicians, as used to be the case before. The role of these foreign consultants thus diminished. 
New local professional models were emerging, challenging the socioeconomical organization of the built environment. In Lebanon, the small consulting firms dominated the market but new multidisciplinary consulting firms were rising. Dar al Handasah, ACE, Khatib and Alami were some of them, based on new strategies and relying on foreign Arab markets. Their founders were mostly trained in American universities (particularly the American University of Beirut) and they reproduced the American model of large consulting firms [59]. The itinerary of the Palestinian and American educated Saba Shiber is very illustrative of the new trend [60]. Until the civil war, they played a limited role in Lebanon, where the French influence in planning remained very strong. In the seventies, IAURP, a French leading public town planning agency, gained several consultancies in Beirut. In 1977, APUR, another French public planning firm, was in charge of the master plan of Beirut's city centre. But Dar al Handasah was for the first time involved in the studies [61].

In Damascus, interestingly, the three firms hired for the new towns on Jabal Qassium and still involved with it at the end of the 1970's, were the Lebanese Dar al Handasah, an English firm, Shatland and Cox, and an American firm, PADCO, while the French were ruled out [62]. The creation of the Studies and Consulting Company in 1981 (SCC) was the next step in the transformation of the Syrian planning landscape. It was established as a multidisciplinary public firm and produced plenty of studies for the Syrian administration. Its staff consisted mostly of Syrian engineers. An important number of them had been trained in Socialist countries. Experts from Poland, Russia and Bulgaria worked in the SCC during the 1980’s [63]. This was clearly in continuity with the Bulgarian and Polish experts involved in Syrian 
planning from the mid fifties. But the foreign experts were now only a minority in a "syrianised" environment.

\section{Conclusion: A contrasting and paradoxical Legacy}

Ecochard was not a bad architect [64] but he himself used to say that he was aware his architectural work was less striking that his planning ideas [65]. Ecochard's first planning experiments in Syria, Lebanon and Morocco, in contrast to Prost or Agache work in the French colonies have not been conceptualized as a "banc d'essai" for the French planning.

But one must recognize the legacy of Ecochard as a planner for the third world. Inspired by the modernist agenda of the CIAM, he attempted to apply it and then adjusted it, for the situation of the third world countries. Three of his main principles can be highlighted. First, town planning is the thing of the State and needs strong public bodies in order to crush the speculation and achieve modernisation projects as conceived by the planner. Second, planning in third world countries has to develop new tools for housing the poor. Ecochard's Moroccan views on this would be later applied in Senegal [66]. But strangely, Ecochard did not praise nor attempted to use his ideas for housing the poor in Lebanon or Syria, despite the fact that he noticed the beginning of slums developing in both countries. Instead, he promoted CIAM like neighbourhoods (like in Mezzeh, in Damascus). The third principle deals with planning in Islamic cities, and it is mainly illustrated in his Damascene work, but could also be showed in Iran (Meshed). In such places, the planner had to reconcile the necessity of modernity with the preservation of heritage. By focusing more on monuments, in his own plans this principle had been at the expense of the traditional urban fabric. 
It is interesting to examine the contrasting fates of Ecochard in Lebanon and Syria. In Lebanon, where only few of his planning ideas have been implemented, Ecochard's ideas represented for a long time a reference point of good practice. This was because of his praise of the strong role of the State and also because, at least until the 1986 IAURIF Metropolitan Beirut Master plan, no other planning conception was available.

In Damascus, the modernist and functionalist ideas of Ecochard were easily accepted. The State was strong enough to implement infrastructures and carry out large housing projects. Ecochard’s legacy is much more about his contested vision of the heritage, which privileged the Islamic monuments and the Roman heritage over the vernacular urban fabric. In the city he so much cherished, Ecochard soon appeared to be the gravedigger of heritage in the eyes of a new generation of planners, architects and citizens.

Ecochard's last commissions in the sixties in Lebanon and Syria illustrate a change in planning history. It seems that both of his master plans represented the last episodes of the grand conception of comprehensive planning, with a foreign chief planner drawing the future on a blank sheet according to his personal understanding of a particular city combined with functionalist principles, and claiming strong implementation power from the State and its administration. These modernist ideas coupled with a personal vision were widely accepted and retained for many years by the increasingly structured national milieus of planners in each country. The rise of the planning bureaucracy in both Beirut and Damascus, the empowerment of the local professionals in the public and the private sectors, the new models of the milieu are new parameters and objects for urban historians in such countries. Understanding the 
circulation and the dissemination of planning paradigms can definitely not be

undertaken without taking into account such a turn.

\section{References}

1. See J.L.Cohen and M. Eleb, Casablanca. Mythes et figures d'une aventure urbaine (Paris: Hazan, 1998) (translated into Casablanca: Colonial Myths and Architectural Ventures (New York: Monacelli Press, 2002) ; J.L.Cohen, 'Michel Ecochard (1905-1985)', in Dictionnaire des orientalistes de langue française, F. Pouillon ed (Paris: Karthala, 2008), 346-348; P. Rabinow, French Modern. Forms and Norms of the Social Environment (Berkeley: Berkeley University Press, 1989); F. Friès, 'Les Plans d'Alep et de Damas, un banc d'essai pour l'urbanisme des Frères Danger (1931-1937)', Revue Du Monde Musulman Et De La Méditerranée, 73 (1994), 311-325 <doi:10.3406/remmm.1994.1684>; M. Ghorayeb, 'L'urbanisme de la ville de Beyrouth sous le Mandat français', Revue Du Monde Musulman Et De La Méditerranée, 73 (1994), 327-339 <doi:10.3406/remmm.1994.1685>.

2. M. Ghorayeb, 'Au croisement des cultures urbaines. L’œuvre de Michel Écochard', Maghreb Machrek Monde Arabe, 143, (1994), 162-173; M. Ghorayeb, "The Work and Influence of Michel Ecochard in Lebanon", in Projecting Beirut. Episodes in the Construction and Reconstruction of a Modern City, Rowe P. and Sarkis H. eds. (Munich, New York: Prestel Verlag, 1998), 106-121. 3. N. de Mazieres, 1985, “Homage”, Environmental Design: Journal of the Islamic Environmental Design Research Centre, 1, 22-25.

4. A.D.King, Colonial urban development : culture, social power, environment (London: Routledge, 2007, $1^{\text {st }}$ ed. 1976), P. Rabinow, French Modern. Forms and Norms of the Social Environment; , G. Wright, The Politics of Design in French Colonial Urbanism (Chicago: University of Chicago Press Chicago,1991).

5. P. Rabinow, French Modern. Forms and Norms of the Social Environment ; H. Vacher, Projection coloniale et ville rationalisée : le rôle de l'espace colonial dans la constitution de l'urbanisme en France, 1900-1931 (Aalborg: Aalborg Univ. Press, 1997).

6. M. Marié, Les terres et les mots (Paris: Méridiens Klincksiek, 1989)

7. J.-C.Frédenucci, 'L'entregent colonial des ingénieurs des Ponts et Chaussées dans l'urbanisme des années 1950-1970', Vingtième Siècle, 79 (2003), 81-93.

8. S.F. Ward, Planning the twentieth century metropolis. The Advanced capitalist world ( Chichester: Wiley Academics, 2002), 395-409.

9. See for instance the theoritisation of the self help by Turner : R. Harris Richard, 'Double Irony : the Originality and Influence of John F.C. Turner', Habitat International, 27 (2003), 245-269.

10. R. Bromley, 'Towards Global Human Settlements : Constantinos Doxiadis as Entrepreneur, Coalition-Builder and Visionary', in J. Nasr and M. Volait (eds.), Urbanism : Imported or Exported. Foreign Plans and Native Aspirations (Chichester: Wiley Academics, 2003,) 316-340.

11. J. Nasr and M. Volait (eds.), Urbanism : Imported or Exported. Foreign Plans and Native Aspirations (Chichester: Wiley Academics, 2003).

12. B. Sanyal, ed., Comparative Planning Cultures (London, New York: Routledge, 2005).

13. R. Cowherd, 'Do Planning Cultures Matter? Dutch and American Models in Indonesian Urban Transformations', in Comparative Planning Cultures, B. Sanyal, ed., 165-192.

14. T. Souami and E. Verdeil, Concevoir et gérer les villes. Milieux d'urbanistes du sud de la Méditerranée (Paris: Anthropos-Economica, 2006).

15. J. Tabet, 'Damas, Beyrouth, regards croisés', in A.M. Bianquis, ed., Damas, miroir brisé d'un Orient arabe (Paris: Autrement, 1992), 136-145; C. Eddé, Beyrouth : Naissance d'une capitale : 1918 1924 (Arles: Actes Sud, 2009); F. Friès, Damas (168-1946). La Mise en place de la ville moderne. Des règlements au plan (unpublished $\mathrm{PhD}$, Université Paris VIII - Institut français d'urbanisme, 2000).

16. The main archives and documentation centers have been, in Lebanon, the documentation center of the Center for Reconstruction and Development (library of the former Planning Ministry), the library of the Order of Engineers of Beirut, the library of the Institut français du Proche-Orient, and the private offices of several Lebanese architects; in Damascus, the library of the Institut français du Proche-Orient (Atelier Vieux Damas); in France, Institut français d'architecture (now Cité de l'architecture et du Patrimoine), Centre d'archives d'architecture du XXe s. and the documentation center of the Housing Ministry (CDU-ISTED, Paris La Défense). 
17. M. el Kallaa, Damas et le temps d'Ecochard. Les temps de l'urbanisme, enquêtes d'histoire orale.unpublished report (Marne-la-Vallée: Institut français d'urbanisme, Laboratoire Théories des mutations urbaines,1993); M. Ghorayeb, Recherche sur les transferts à l'étranger et modalités de retour des théories et des pratiques urbanistiques ; le cas ECOCHARD, (Marne-la-Vallée, : Laboratoire TMU, URA-CNRS 1244, déc. 1993).

18. I thank Roula Khater who helped in arranging and translating two of these interviews in Damascus in April 2008.

19. V. Bradel Vincent, Michel Écochard (1905-1985), roneo., (Paris: Bureau de la recherche architectural/Institut français d'architecture, 1986); M. Ghorayeb, 'Au croisement des cultures urbaines. L’œuvre de Michel Écochard', Maghreb Machrek Monde Arabe.

20. F. Friès Franck, 'Les plans 'Alep et de Damas, un banc d'essai pour l'urbanisme des frères Danger (1931-37)', Revue du monde musulman et de la Méditerranée, 73-74 (1996), 311-326

21. H. Zeifa, 'Les élites techniques locales durant le Mandat français en Syrie (1920-1945)', in Les mandats français et anglais dans une perspective comparative, N. Meouchy, P. Sluglett eds., (Leyden: Brill, 2003), 497-536.

22. M. Ghorayeb, Recherche sur les transferts à l'étranger et modalités de retour des théories et des pratiques urbanistiques ; le cas ECOCHARD.

23. M. Ghorayeb, 'The Work and Influence of Michel Ecochard in Lebanon'.

24. V. Bradel Vincent, Michel Écochard (1905-1985); M. Dion, 'Michel Ecochard (1905-1985)', notice biographique, extracted from M. Dion, Notices biographiques d'architectes français (Paris :

Ifa/Archives d'architecture du XXe siècle, 1991), 2 vol., available online : http://

archiwebture.citechaillot.fr/...FRAPN02_ECOMI_REPERAGE.pdf; J.-L. Cohen and M. Eleb, Casablanca, mythes et figures d'une aventure urbaine; M. Ecochard, Casablanca, le roman d'une ville (Paris: Edition de Paris, 1955).

25. J.-L. Cohen and M. Eleb, Casablanca, mythes et figures d'une aventure urbaine; T.Avermaete, 'Framing the Afropolis. Michel Ecochard and the African City for the Greatest Number', in L'Afrique, c'est chic: Architectuur en planning in Afrika 1950-1970 = Architecture and planning in Africa 19501970 (Rotterdam : NAi Uitgevers Pub.-OASE n82, 2010), 77-101.

26. T. Avermaete, 'Framing the Afropolis. . Michel Ecochard and the African City for the Greatest Number'.

27. For a full bibliography, see M. Dion, Notices biographiques d'architectes français.

28. S. Abdulac,'Damas : les années Ecochard (1932-1982)', Cahiers de la recherche architecturale, 11 (1982), 32-44.

29. M. Ghorayeb, 'L’intervention de Michel Écochard : projets et réalisations', in Madina, cité du monde, special issue on Saida, (Paris: Association Madina-Cité du Monde, 1997), 71-81.

30. M. Ghorayeb, 'The Work and Influence of Michel Ecochard in Lebanon'.

31. H. Sarkis Hashim, Circa 1958: Lebanon in the Pictures and Plans of Constantinos Doxiadis (Beirut: Dar An-Nahar, 2003); E. Verdeil, 'Politics, Ideologies and Professional Interests : Foreign versus local experts in Lebanon during the mandate of Fouad Chehab', in Imported or Exported Urbanism?, J. Nasr and M. Volait, eds. (Chichester: Wiley, 2003), 290-315. 2011.

32. I. L. Gendzier, Notes from the minefield : United States intervention in Lebanon and the Middle East, 1945-1958 (New York: Columbia University Press, 1997).

33. "Il y a vingt ans que je pense au problème de Beyrouth, je crois que sur un certain nombre de points, le temps ne m'a pas donné tort et je suis heureux si la patience que j'aurais mise au service de cette ville pouvait, grâce à votre aide, donner quelques résultats" (Letter from M. Ecochard to C. Moharram, technical advisor of F. Chehab, President of the Republic of Lebanon, on the 28th of april 1961 (IFA-Fonds Ecochard box 32). (I have been thinking about the problem of Beirut for twenty years, I believe that for a certain number of points, time hasn't proved me wrong and I am happy if the patience I have dedicated to the service of this city could, thanks to your help, give some results) 34. Ministère du Plan, Etudes préliminaires du plan directeur de Beyrouth et de sa banlieue, par Ecochard, Sérof, Banshoya Tager, suivant les directives et sous le contrôle de la Commission de Beyrouth et sa banlieue, vol. Projets, roneo., n.d. [1963].

35. See E. Verdeil, Beyrouth et ses urbanistes. Une ville en plans (1946-1975) (Beirut: Presses de l'IFPO, 2010). For instance, the Floor area ratios in the 'Zone des collines' rose by $50 \%$, in the Choueifate area by $20 \%$, in the existing villages by $25 \%$ and in the mixed zone of the existing agglomeration, by $65 \%$.

36. E. Verdeil, Beyrouth et ses urbanistes. Une ville en plans (1946-1975). 
37. E. Verdeil and E. Longuenesse, 'Traductions en arabe des termes urbanisme et town planning (Liban-Syrie-Egypte)' in Langages techniques et spécialisés de l'urbain , Coudroy de Lille Laurent, Ratouis Olivier eds., (Paris : Editions de l'UNESCO-EHESS, forthcoming).

38. In 1957, Morozov, a Bulgarian planner, drafted a master plan for Damascus. It was not approved. It would have led to wide destructions in the historic core through the opening of streets between the Citadel toward the Central Bank Several interviewees recalled that episode (Interview with Jabbour, 2008 and with Shakar, 2009). See also G. Degeorge, Damas des ottomans à nos jours (Paris:

L'Harmattan, 1994), 197.

39. Interview with Alexius Shakar, former head of the planning administration in Syria, 28th of July 2009, Montreal.

40. Interview of Saadallah Jabbour, Damascus, 25 ${ }^{\text {th }}$ of april 2008.

41. J.-C. David 'Alep, Damas : la fonction de capitale comme facteur de transformation de la ville', Bulletin de la Société de géographie du Languedoc, 30 (1986), 369-385.

42. Interview of Saadallah Jabbour, Damascus, $25^{\text {th }}$ of april 2008.

43. 'Il faudra que les habitants de Damas se rendent compte qu'une citadelle de Salah ed Din comme celle de Damas vaut bien un Louvre de Paris et qu'elle doit, tout aussi bien que la grande mosquée ou les parfaits monuments Ayoubites du quartier El-Akrad, servir à la mise en valeur de la ville en rentrant dans la vie propre de Damas non comme des pièces archéologiques mais comme une partie toujours vivante de la Nation', M. Ecochard, G. Banshoya, Plan directeur de Damas. Rapport justificatif, 1968, Préambule. (The inhabitants of Damascus will have to realise that a Salah ed Din citadel like the one of Damascus is worth a Louvre in Paris and must help, exactly like the Great Mosque or the perfect Ayoubid monuments from the neighborhood Al-Akrad, develop the city by entering the proper life of Damascus not like archeological pieces but like a still vivid part of the Nation').

44. S. Abdulac, 'Damas : les années Ecochard (1932-1982)', Cahiers de la recherche architecturale, 11 (1982), 32-44.

45. See C. Chaline, 'Damas ou les ambigüités de la planification urbaine', in Beaujeu-Garnier J., Dézert B., eds., La grande ville, enjeu du XXI siècle, (Paris: PUF, 1989), 243-254; I. Labeyrie and M. Dummi, 'Dummar, cité satellite de Damas : les conditions de réalisation contemporaine', Les cahiers de la recherche architecturale, $\mathrm{n}^{\circ} 10-11$ (1982), 140-149. And interview with Hicham el Sati, Damascus, $24^{\text {th }}$ of april 2008.

46. G. Degeorge, Damas des ottomans à nos jours.

47. G. Degeorge, Damas des ottomans à nos jours.

48. M. el Kallaa, Damas et le temps d'Ecochard. Les temps de l'urbanisme, enquêtes d'histoire orale.

49. M. Ghorayeb, Recherche sur les transferts à l'étranger et modalités de retour des théories et des pratiques urbanistiques ; le cas ECOCHARD.

50. E. Verdeil, 'Politics, Ideologies and Professional Interests : Foreign versus local experts in Lebanon during the mandate of Fouad Chehab'.

51. M. Ecochard, 'L'urbanisme', Horizons Techniques du Moyen-Orient, 2 (1963), 1-5; J. Eddé and G. Attara, 'Que faut-il penser du plan directeur des banlieues de Beyrouth', Horizons Techniques du Moyen-Orient, 5 (1965), 20-23.

52. Interview with Jean-Claude David, 20th February 2008, Lyon.

53. F. Trad, 'Réseau des grandes voies de circulation à Beyrouth et dans sa banlieue. Considérations critiques', Al Mouhandess, 3 (1964), 24-31. For further analysis of that debate, see E. Verdeil, 'Politics, Ideologies and Professional Interests : Foreign versus local experts in Lebanon during the mandate of Fouad Chehab'.

54. See $L$ 'Orient, the $2^{\text {nd }}, 8^{\text {th }}, 11^{\text {th }}, 16^{\text {th }}$ and $23^{\text {rd }}$ June 1964 ; Also, in the journal of the Order of engineers of Beirut : Al Mouhandess, 1(november 1963), 40-45 ; 4 (april 1965), 1 ('éditorial') ; 6 (january 1966), 1 ('éditorial'), 'Les nouvelles de l’Ordre', 8 (December 1966), 22 ; 10 (december 1967), 1 (editorial on the consulting engineer) ; 13 (december 1968), 1 ('éditorial') ; 16 (october 1969), 11. 55. C. Salamandra, A New Old Damascus: Authenticiy and Distinction in Urban Syria, Indiana Series in Middle East Studies (Indianapolis: Indiana University Press, 2004); M. el Kallaa, Damas et le temps d'Ecochard. Les temps de l'urbanisme, enquêtes d'histoire orale.

56. E. Longuenesse ed., Bâtisseurs et bureaucrates, Ingénieurs et Société au Maghreb et au MoyenOrient, (Lyon: Maison de l'Orient Méditerranéen, coll. "Etudes sur le Monde Arabe", n 4, 1990).

57. Interview with Alexius Shakar, the 28th of July 2009, Montreal.

58. E. Verdeil, Beyrouth et ses urbanistes. Une ville en plans (1946-1975).

59. E. Verdeil, 'State development policy and specialised engineers. The case of urban planners in postwar Lebanon', Savoir Travail Société / Knowledge Work Society 5, 1 (2008), 29-51 (available on internet : http://halshs.archives-ouvertes.fr/halshs-00261163/fr/). 
60. J. Nasr, 'Saba Shiber, 'Mr. Arab Planner'. Parcours professionnel d'un urbaniste au Moyen-Orient', Géocarrefour 80, 3(2005): 197-206.

61. J. Nasr and É. Verdeil, 'The reconstructions of Beirut', in The city in the Islamic world, S. K. Jayyusi, R. Holod, A. Petruccioli, et A. Raymond, (Leiden: Brill, 2008), 1116-1141.

62. See Direction des relations économiques extérieures - Agence de coopération technique industrielle et économique, service de coopération technique du ministère de l'Equipement, Mission d'urbanisme en Syrie, Damas-Dimas, Michel Lanthonie, Architecte DESA, du 6 au 17 octobre 1976. Document consulted at the library of ISTED, Paris La Défense. PADCO was at the same time the consultant hired by the Egyptian governement to set up a national urban planning strategy, which was released in 1982(M. Volait, 'Les premiers pas de la profession d'urbaniste en Egypte: repères sur la constitution d'un champ de pratique professionnelles', in T. Souami, ed., Cultures et milieux urbanistiques dans le Sud Méditerranéen, vol. 2, Analyse par pays, Programme de recherche urbain, Marne-la-Vallée, LTMU-Institut français d'urbanisme, 2004, 47-69. Available online: http://www.gemdev.org/prud/rapports/rapport16_2.pdf).

63. E. Longuenesse, 'L'exercice de l'urbanisme en Syrie', in Concevoir et gérer les villes. Milieux urbanistiques au Sud de la Méditerranée, T. Souami, E. Verdeil Eric, ed. (Paris: AnthroposEconomica, 2006), 172-173.

64. See for instance the rather laudatory remarks about his work as an architect in Lebanon : J. Tabet and al., Beyrouth, (Paris: Institut français d'architecture, 2001).

65. « Je suis assez lucide pour savoir que je n'ai rien apporté à l'architecture moderne », (I am lucid enough to know that I haven't brought anything to modern architecture). Quotation without date nor place, in M. Dion, Notices biographiques d'architectes français.

66. T. Avermaete, 'Framing the Afropolis. Michel Ecochard and the African City for the Greatest Number', in T. Avermaete and J. Lagae, L'Afrique, C'est Chic : Architectuur En Planning in Afrika 1950-1970 = Architecture and Planning in Africa 1950-1970, (oase ; 82), 1 vol (Rotterdam: NAi Uitgevers Pub., 2010), 77-100. 